\title{
Effect of eyestalk ablation in Eriocheir sinensis on physiological and biochemical metabolism
}

\author{
Jiangli Wu, Xianjiang Kang ${ }^{*}$, Shumei Mu, Zhihuan Tian \\ College of Life Science, Hebei University, Baoding, China; ${ }^{*}$ Corresponding Author: xjkang218@126.com \\ Received 24 April 2013; revised 24 May 2013; accepted 9 June 2013 \\ Copyright (C) 2013 Jiangli Wu et al. This is an open access article distributed under the Creative Commons Attribution License, which \\ permits unrestricted use, distribution, and reproduction in any medium, provided the original work is properly cited.
}

\section{ABSTRACT}

Eyestalk ablation is the most common procedure to induce gonadic maturation of Eriocheir sinensis. In addition to reproduction, other physiological and metabolic processes are also affected by the removal of X-organ sinus complex located in the eyestalk. In this study, we studied physiological and biochemical effects of eyestalk ablation of $E$. sinensis, and the results were as follows. The amylase activity of male crabs with unilateral or bilateral eyestalk ablation was increased with the days increasing, and the maximal value was on the 20th day $(P<0.05)$, while the amylase activity of female crabs did not change significantly. Both pepsin activity and trypsin activity of males and females didn't have significant change. The total lipids of serum of male crabs were lower within the first 5 and 10 days $(P<0.05)$, and gradually recovered to initial level. Female crabs' serum total lipids were higher than control group, and the maximum appeared in the middle of the experiment. The research results had certain guidance for scientific feeding and the proportion of artificial diet in the breeding of crabs with eyestalk ablation.

Keywords: Eriocheir sinensis; Eyestalk Ablation; Physiological and Biochemical

\section{INTRODUCTION}

Eyestalk ablation has been used to improve the production of crustaceans. Besides improving reproductive performance, it could also cause other changes that we do not fully understand. X-organ-sinus gland system is neuroendocrine organ in optic ganglia of crustaceans' eyestalk which could synthesize and excrete several kinds of neuropeptide. These hormones could regulate several metabolic processes [1,2].

There have been reports on the effects of unilateral and bilateral eyestalk ablation of crustaceans [3-5], but effects of $E$. sinensis (hereafter called crab) were fewer. This experiment studied the digestive enzyme activity of hepatopancreas and serum lipids of crabs with eyestalk ablation, understood the effects of eyestalk ablation on metabolic and provided a reference of proportion of forage.

\section{MATERIALS AND METHODS}

\subsection{Experiment Crabs}

Juvenile crabs were bought from Baiyangdian Lake, Hebei Province, China.

\subsection{Methods}

\subsubsection{The Grouping of Crabs}

Crabs were transferred to the tanks with water levels of $10 \mathrm{~cm}$, oxygen filling, feeding corn kernels at regular time, changed the water every day, 7 days after adaption, a total of 240 female and male crabs $(15-25 \mathrm{~g})$ were ablated unilaterally (left eyestalk only) or bilateral, and applying burn to the wound to minimize fluid loss and help coagulation. First, we took out blood and hepatopancreas from the control group(non ablated), then, every 5 days, we took out blood and hepatopancreas from crabs with unilateral and bilateral eyestalk ablation to determine a serious of index.

\subsubsection{The Preparation of Samples}

Hepatopancreas wet weight were weighed accurately, then we added precooling two steamed water to hepatopancreas with a proportion of $1: 4(\mathrm{~g} / \mathrm{mL})$, samples were homogenized by Ultrasonic Cell Disrupter System, then homogenate were centrifuged $15 \mathrm{~min}$ at $10,000 \mathrm{rpm}$ at $4^{\circ} \mathrm{C}$, at last, we took clear liquid with multiply dilution to go on the enzyme activity. 
We cut off the crabs' third or fourth step foot, collecting haemolymph in $1.5 \mathrm{~mL}$ Eppendorf centrifugal tube, $4^{\circ} \mathrm{C}$ quietly placed over-night, low temperature centrifuged $\left(4^{\circ} \mathrm{C}, 6000 \mathrm{r} / \mathrm{min}, 20 \mathrm{~min}\right)$, then draw serum and stored it in centrifugal tube at $-80^{\circ} \mathrm{C}$ refrigerator.

\subsubsection{The Measurement of Amylase Activity}

Took two tubes, one was blank, and the other was test, then added $0.04 \%$ soluble starch buffer $1 \mathrm{~mL}$, reacting 2 - $5 \mathrm{~min}$ at $37^{\circ} \mathrm{C}$, and then added $0.02 \mathrm{~mL}$ test fluid in to test tube but not blank tube, blending, and then kept them in a $37^{\circ} \mathrm{C}$ water bath for $7.5 \mathrm{~min}$, then, we added iodine diluent $1 \mathrm{~mL}$ separately, at last, we added deionized water $6 \mathrm{~mL}$ in to test tube, and $6.02 \mathrm{~mL}$ in to blank tube, reading absorbance at $660 \mathrm{~nm}$ wavelength with the deionized water absorbency of 0 .

The formula of Amylase activity:

$$
\frac{\text { blank tubeA660 }- \text { test tubeA660 }}{\text { blank tubeA660 }} \times 800
$$

One unit of amylase activity was defined as $10 \mathrm{mg}$ starch that was hydrolysed by the reaction of $30 \mathrm{~min}$ between $100 \mathrm{~mL}$ enzyme filtrate and starch at $37^{\circ} \mathrm{C}$.

\subsubsection{The Pepsin and Trypsin Activity Were} Measured Using the Method of Liu et al. [6]

One unit of enzyme activity ( $\mu \mathrm{g} / \mathrm{min})$ was defined as 1 $\mu \mathrm{g}$ tyrosine that was produced by hydrolyzing casein per minute at $37^{\circ} \mathrm{C}$.

The enzyme activity units (U) divided by the soluble protein (mg), which was enzyme specific activity, with the show of $\mathrm{U} / \mathrm{mg}$.

\subsubsection{The Total Lipids of Serum Were Measured by Methods of Vanillin Coloration}

\subsubsection{Data Processing}

All the data were showed as mean \pm standard deviation (Mean $\pm \mathrm{SD}$ ), the experiment results were statistical and analysed by SPSS17.0 software, using single factor (One-Way ANOVA) to analyse, and significant difference critical value was 0.05 .

\section{RESULTS}

\subsection{Effects of Eyestalk Ablation on Digestive Enzyme}

For male crabs, no matter unilateral eyestalk ablation or bilateral eyestalk ablation, with the increase of days, amylase activity presented a trend with gradually rise, and the maximum was at 20th days and they have significant difference with the control group $(P<0.05)$ (Figure 1). As for female crabs (Figure 2), no matter unilateral eyestalk ablation or bilateral eyestalk ablation,

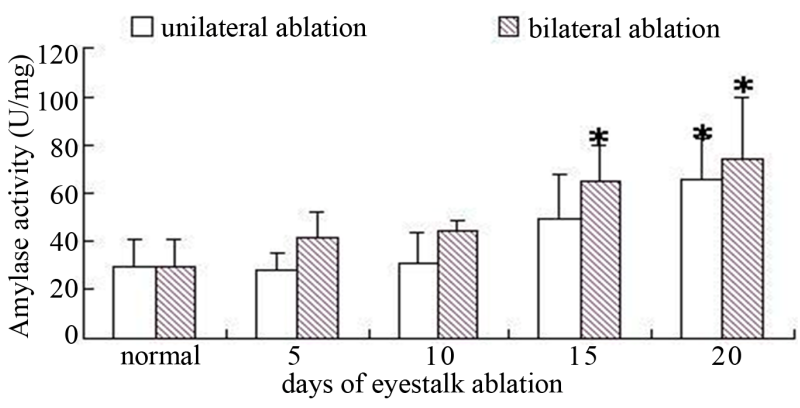

Figure 1. The amylase activity of hepatopancreas after male crabs ablated on nonablated in different term ( ${ }^{*}$ showed significant difference).

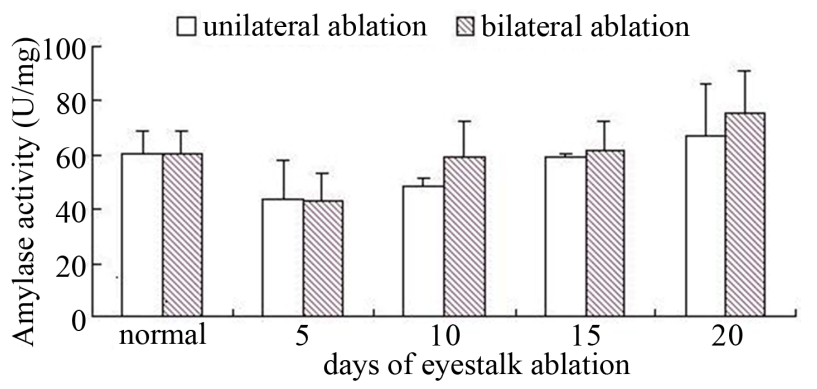

Figure 2. The amylase activity of hepatopancreas after female crabs ablated on nonablated in different term.

compared with control group, amylase activity did not have obvious change $(P>0.05)$. Through experimental results we found that, after eyestalks were cut down, both pepsin and trypsin activity did not change significantly $(P>0.05)$ (Figures 3-6).

\subsection{Effects of Eyestalk Ablation on Serum Total Lipids}

From the experiment results (Figure 7), we could found, male crabs' serum total lipids down significantly in the first 5 - 10 days after eyestalks were cut off $(P<$ $0.05)$, then with the extension of the days, the serum total lipids restored to its original level gradually. As for female crabs, no matter unilateral or bilateral eyestalk ablation, the serum lipids was higher than the control group, maximum peak appeared in the middle of experiment (Figure 8).

\section{DISCUSSION}

Crustaceans' digestive enzymes were influenced by many factors. They were related to different growth and development periods of animals [7], meanwhile, they were influenced by seasonal change, forage and so on [8]. Furthermore, some endocrine factors could also affect enzymes activity by stimulating or suppressing the synthesis of enzymes [9].

The studies on digestive enzyme activity of Penaeus chinensis showed that different digestive enzymes had 


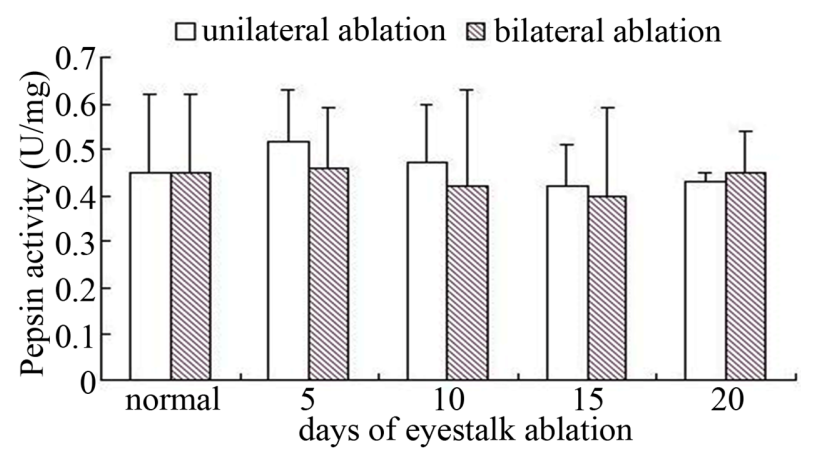

Figure 3. The pepsase activity of hepatopancreas after male crabs ablated on nonablated in different term.

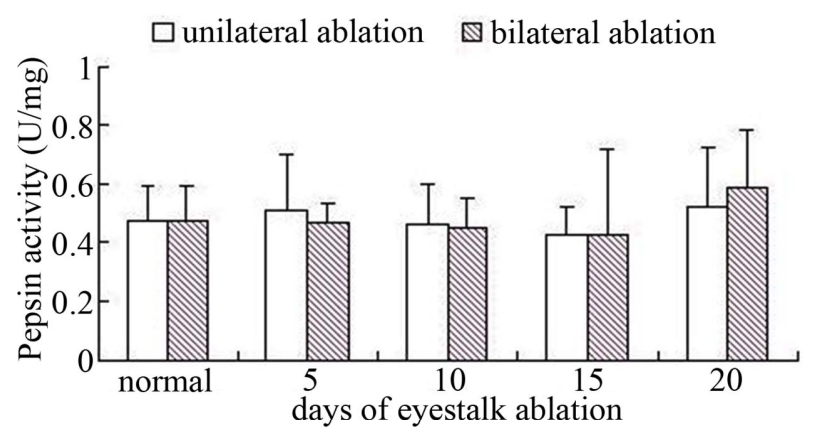

Figure 4. The pepsase activity of hepatopancreas after female crabs ablated on nonablated in different term.

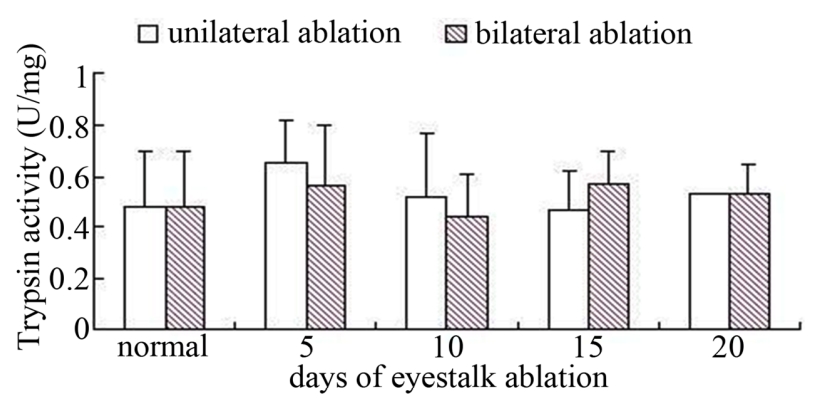

Figure 5. The trypsin activity of hepatopancreas after male crabs ablated on nonablated in different term.

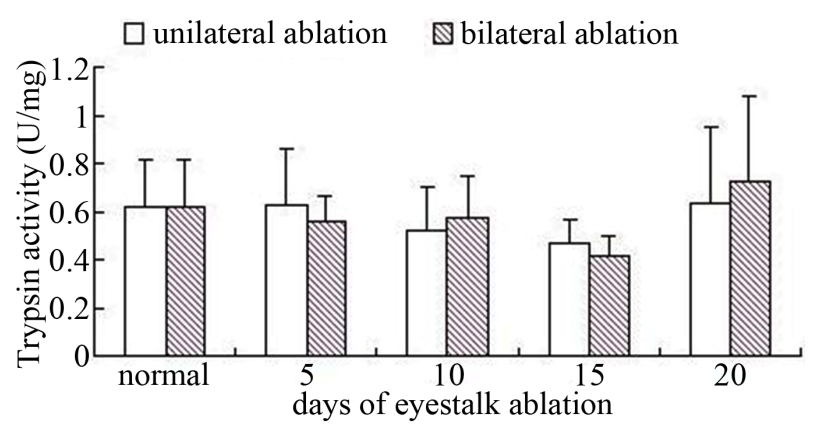

Figure 6. The trypsin activity of hepatopancreas after female crabs ablated on nonablated in different term.

their own adjustment mechanism [10], and some other researchers also found that different larval crustaceans'

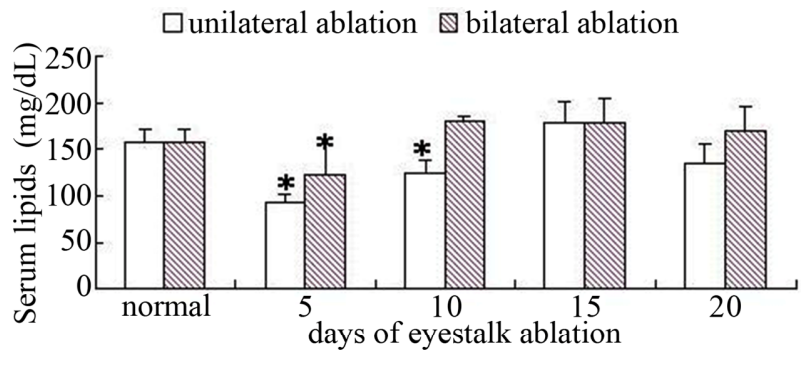

Figure 7. The blood lipid after male crabs ablated on nonablated in different term ( ${ }^{*}$ showed significant difference).

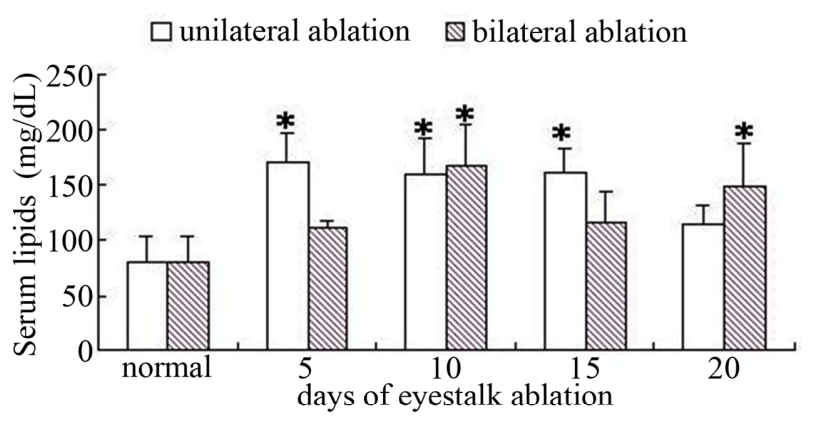

Figure 8. The blood lipid after female crabs ablated on nonablated in different term ( ${ }^{*}$ showed significant difference).

digestive enzymes had their own regulating system [11-13]. Some studies also noted that because of different ecological position, feeding and living environment, the changing trend of different kinds of digestive enzymes had a lot of differences.

\subsection{Effects of Eyestalk Ablation on Amylase of Hepatopancreas}

Amylase was a kind of digestive enzyme that mainly digested starch and carbohydrate. After male crabs' eyestalks were cut off, the activity of amylase kept increasing. The possible reason of it was that eyestalk ablation speeded up the development of testis, and spermatic development needed to consume large amounts of energy. And monosaccharide was the most directly using form of animals, with the extension of days, spermatic development continued to mature, and the requirements to glucose also constantly increased, while amylase was the main digestive enzyme that hydrolyzed carbohydrate, so the amylase activity also increased accordingly. And the amylase activity was higher in bilaterally ablated male crabs, the reason was that with bilateral eyestalk ablation, $\mathrm{X}$-organ-sinus gland complex was totally broken, and this removed the inhibition of the spermatic development, and more energy was needed with the faster development. But when female crabs' eyestalks were cut off, amylase activity declined at first, but with not significant change, then recovered to a normal level. The possible reason was that ovarian development needed more energy, but 
the energy stored in hepato-pancreas was not able to meet the needs, meanwhile, female crabs may had another regulating system, when the eyestalks were ablated, this regulating system played a role to make amylase activity recover to initial level. So if we cut off crabs' eyestalk, we need to feed some food with higher starch to fulfill their growth and development especially to male crabs.

\subsection{Effects of Eyestalk Ablation on Digestive Enzyme of Hepatopancreas}

Crustaceans' pepsin and trypsin possessed an important portion in vivio [14], but they did not have obvious content with each other [15]. With the ablation of eyestalk, gonadal development speeded up, and gonad needed to accumulate vast nutrition and energy before its development. The hepatopancreas was the main place for accumulating energy, and this accumulation was affected by environmental factors especially the forage. Because gonadal development required a lot of energy, the nutrition and energy which were stored in hepatopancreas were often consumed soon.

No matter male crabs or female crabs, with the ablation of eyestalk, the effects on pepsin and trypsin did not have obvious change compared with the control, which meant eyestalk ablation did not have distinct effects on the two kinds of digestive enzymes. The possible reason was that enzyme activity was influenced by various elements, and just ablation of eyestalk could not make the enzyme activity produce very big change. Or we could say that animals themselves had a self control system, they could able to maintain their own metabolism in a relatively stable level.

In this experiment, we could find that amylase activity was the highest in three digestive enzymes. We guessed that the demand of saccharides was higher than other material, so we should pay attention to the proportion of nutrients of forage to meet the growth of crabs.

\subsection{Effects of Eyestalk Ablation on Serum Total Lipids}

The existing researches showed that the lipids played a very important role in growth reproduction of many crustaceans. The main organ of crustacean absorption, machining and storage of lipids was hepatopancreas, and studies have found that the lipids in hepatopancreas were transferred to the ovary through the blood [16]. Crustaceans needed to consume larges of energy in the reproduction period, and the demand for lipids would also increase in gonadal development period. The lipids in hepatopancreas could not meet the needs of the gonadal development, and soon the lipids were processed by hepatopancreas from forage and were transported to the ovary.

Serum total lipids were the general call of all sorts of lipids component in serum, including triglycerides (TG), phospholipids, cholesterol (TC) and a small amount of free fatty acid and so on, but the main was total cholesterol and triglyceride. Cholesterol as a precursor of hormone synthesis of steroids [17] was a kind of neutral fat. It played an important role in reproduction and secretion of crustaceans [18]. Because crustaceans couldn't synthesize cholesterol in the body, they stored cholesterol in hepatopancreas and muscles before laying eggs, in the periods of gonad development, the cholesterol was assembled and transported to the ovary. The research has found that cholesterol in ovary of $P$. duorarum was gradually increasing in the periods of sexual maturity [19], the cholesterol in the blood of china shrimp kept increasing in the early periods of gonad maturation, and down with no obvious change in the later periods [20].

Another kind of neutral fat was triglycerides, which was the main energy of shrimp, eggs and larvae before feeding [21]. Lipids, especially triglycerides, were not only the main energy material in the process of crustaceans' growth, and at the same time, it also had the function of energy store [22].

In this experiment, when female crabs' eyestalks were cut off, the total lipids of the serum were higher than control group. It could be concluded that after the ablation of female crabs' eyestalk, triglyceride and cholesterol were sent to ovary through blood continually, this could provide energy for ovarian growth; meanwhile, it also was a kind of way that parent crabs saved energy for their off-springs. And after the ablation of male crabs' eyestalk, the contents of the lipids decrease significantly in the early stage, and gradually increase with the extension of time. We inferred that spermary needed more lipids during its development, the lipids stored in heaptopancreas was not able to meet the needs of gonadal development of male crabs, so the lipids of blood which as a transportation passageway were also reduced. So in the production of male crabs with eyestalk ablation, we should pay more attention to adding some food which contained abundant lipids to guarantee a smooth growth.

\section{ACKNOWLEDGEMENTS}

This manuscript was supported by Natural Science Foundation of China (31272309 and 31202000) and Natural Science Foundation of Hebei Province P. R. China (C2011201028).

\section{REFERENCES}

[1] Beltz, B.S. (1988) Crustacean neurohormones. In: Laufer, H. and Downer, R.G.H., Eds., Endocrinology of Selected Invertebrate Types (Invertebrate Endocrinology), Alan R Liss, Inc., New York, 235-258. 
[2] Chang, E.S. (1992) Endocrinology. In: Fast, A.W. and Lester, L.J., Eds., Marine Shrimp Culture: Principles and Practices, Elsevier, Amsterdam, 53-91.

[3] Tamone, S.L., Adams, M.M. and Dutton, J.M. (2005) Effect of eyestalk-ablation on circulating ecdysteroids in hemolymph of snow crabs, Chionoecetes opilio: Physiological evidence for a terminal molt. Integrative \& Comparative Biology, 45, 166-171. doi:10.1093/icb/45.1.166

[4] Soundarpandian, P. and Ananthan, G. (2008) Effect of unilateral eyestalk ablation on the biochemical composition of commercially important juveniles of Macrobrachium malcolmsonii (H. Milne Edwards). International Journal of Zoological Research, 4, 106-112. doi:10.3923/ijzr.2008.106.112

[5] Sainz, H.J., Racotta, I., Dumas, S. and Hernandez, L.J. (2008) Effect of unilateral and bilateral eyestalk ablation in Litopenaeus vannamei male and female on several metabolic and immunologic variables. Aquaculture, 283, 188-193. doi:10.1016/j.aquaculture.2008.07.002

[6] Liu, Y.M., Zhu, J.Z., Wu, H.Y. and Shi, D.Z. (1991) Studies on digestive enzymes and amino acid of larval and post larval stages of prawn Penaeus chinensis. Oceanologia et Limnologia Sinica, 22, 571-575.

[7] Fernandez, I., Oliva, M., Carrillo, O. and Van Wormhoudt, A. (1997) Digestive enzyme activities of Penaeus notialis during reproduction and moulting cycle. Comparative Biochemistry and Physiology, 118, 1267-1271. doi:10.1016/S0300-9629(97)86802-8

[8] Jones, D.A., Kumlu, M., Le Vay, L. and Fletcher, D.J. (1997) The digestive physiology of herbivorous, omnivorous and carnivorous crustacean larvae: A review. Aquaculture, 155, 285-295. doi:10.1016/S0044-8486(97)00129-4

[9] Van Wormhoudt, A. (1974) Variation of the levels of the digestive enzymes during the intermolt cycle of Palaemon serratus: Influence of the season and effect of eyestalk ablation. Comparative Biochemistry and Physiology, 49, 707-715. doi:10.1016/0300-9629(74)90899-8

[10] Pan, L.Q. and Wang, K.X. (1997) The experimental studies on activities of digestive in the larvae penaeus chinensis. Journal of Fisheries of China, 21, 26-31.

[11] Tang, H., Li, S.J., Wang, G.Z. and Lin, Q.W. (1995) The Experimental studies on the digestive enzyme activities in the larvae of the mud crab Scylla serrata (Forskal). Journal of XiaMen University-Natural Science, 34, 8893.

[12] Biesiot, P.M. and Capuzzo, G.M. (1990) Changes in digestive enzyme activities during early development of the
American lobster Homarus americanus MILNE EDwards. Journal of Experimental Marine Biology and Ecology, 136, 107-122. doi:10.1016/0022-0981(90)90190-N

[13] Lovett, D.L. and Felder, D.L. (1990) Ontogenetic change in digestive enzyme activity of larval and postlarval white shrimp Penaeus setiferus. Biological Bulletin, 178, 144159. doi: $10.2307 / 1541973$

[14] Van Wormhoudt, A., Sellos, D., Donval, A., Plaire-Goux, S. and Le Moullac, G. (1995) Chymotrypsin gene expression during the intermolt cycle in the shrimp Penaeus vannamei (Crustacea; Decapoda). Cellular and Molecular Life Science, 51, 159-163. doi:10.1007/BF01929362

[15] Ezquerra, J.M., Garcla-Carreno, F.L. and Haard, N. (1997) Effects of feed diets in digestive proteases from the hepatopancreas of white shrimp (Penaeus vannamei). Journal of Food Biochemistry, 21, 401-419. doi:10.1111/j.1745-4514.1997.tb00206.x

[16] Teshima, S., Kanazawa, A., Koshio, S. and Horinouchi, K. (1988) Lipid metabolism in destalked prawn Penaeus japonicus: Induced maturation and accumulation of lipids in the ovaries. Bulletin of the Japanese Society of Scientific Fisheries, 54, 1115-1122. doi:10.2331/suisan.54.1115

[17] Wang, Q., Zhao, Y.L., Ma, Q. and Chen, L.Q. (2004) Seasonal changes of biochemical components in reproductive system of male Chinese mitten-handed crab (Eriocheir sinensis). Oceanologia et Limnologia Sinica, 35, 351-357.

[18] Quackenbush, L.S. (1986) Crustacean endocrinology: A review. Journal of Fisheries and Aquatic Sciences, 43, 2271-2282. doi:10.1139/f86-278

[19] Gehring, W.R. (1974) Maturational changes in the ovarian lipid spectrum of the pink shrimp, Penaeus duorarum duoraum Burkenroad. Comparative Biochemistry and Physiology, 49, 511-524. doi:10.1016/0300-9629(74)90563-5

[20] Wu, Y., Sun, J.M. and Zhou, Z.C. (2003) Variations in digestive enzyme activity and tissue biochemical composition of Penaeus chinensis broodstock during reproductive cycle. Journal of Fisheries of China, 27, 550-557.

[21] Ward, D.G.., Middleditch, B.S., Missler, S.R. and Lawrence, A.L. (1979) Fatty acid changes during larval development of Penaeus setiferus. Proceeding of the World Mariculture Society, 10, 464-471. doi:10.1111/j.1749-7345.1979.tb00042.x

[22] Harrison K.E. (1990) The role of nutrition in maturation, reproduction and embryonic development of decapod crustaceans: A review. Journal of Shellfish Research, 9, $1-28$. 